\title{
Minichromosome maintenance (MCM) and AgNOR proteins expression in desmoid tumours: a tissue microarray analysis
}

\author{
Tomasz Ferenc ${ }^{1}$, Janusz Kopczyński ${ }^{2}$, Liliana Stalińska ${ }^{1}$, Dariusz Tosik ${ }^{3}$, \\ Małgorzata Sidor' ${ }^{2}$, Dobrosława Lopaczyńska ${ }^{1}$, Andrzej Kulig ${ }^{4}$, Adam Dziki ${ }^{5}$ \\ and Jacek Sygut ${ }^{2}$
}

\author{
${ }^{1}$ Department of Biology and Medical Genetics, Medical University, Łódź, Poland \\ ${ }^{2}$ Department of Neoplasm Pathology, Świętokrzyski Centre of Oncology, Kielce, Poland \\ ${ }^{3}$ Department of Histology and Tissues Ultrastructure, Medical University, Łódź, Poland \\ ${ }^{4}$ Department of Clinical Pathomorphology, Institute Polish Mother's Health Centre, Łódź, Poland \\ ${ }^{5}$ Department of General and Colorectal Surgery, Medical University, Łódź, Poland
}

\begin{abstract}
In the present study, nuclear proliferative proteins: MCM2, MCM5, MCM7, Ki-67 and AgNORs expression was assessed in paraffin sections from sporadic desmoid tumours using a tissue microarray (TMA)-based immuno- and histochemistry, respectively. Nuclear expression of MCM7, where the percentage of positive cells was $0.87 \%$ ( \pm 1.64$)$ (range $0-5 \%)$, was found in $4 / 20(20.0 \%)$ cases. In 32/32 (100\%) of the examined desmoid cases no expression of nuclear proteins MCM2 and MCM5 was detected. Nuclear expression of Ki-67 was observed in 4/21 (19\%) cases. Paraffin sections from 30 cases of desmoid tumours were silver-stained to visualize AgNORs. The following AgNOR parameters were calculated: mean AgNOR number per nucleus $(N)$, mean AgNOR area per nucleus, mean AgNOR dot area per nucleus $(A)$, and mean AgNOR content $(C=N / A)$. In the investigated group the mean values of AgNOR parameters were the following number: 4.34 ( \pm 0.11$)$; area: $0.74 \mu \mathrm{m}^{2}( \pm 0.19)$; dot area: $0.18 \mathrm{~m}^{2}( \pm 0.01)$, and $A g N O R$ content: $23.73( \pm 1.85)$. The mean AgNOR number per nucleus and mean AgNOR content in desmoid tumours were statistically significantly higher as compared to the controls (tonsil tissue) $(\mathrm{p}<0.001)$. This study observed low level of MCM7 and Ki-67 and lack of MCM2, MCM5 proteins expression which may explain commonly known low mitotic activity of desmoid tumour cells. The morphology of dots related to AgNORs (number, area) and their morphometric parameters point to elevated transcriptional activity of desmoid cells.
\end{abstract}

Keywords: MCM proteins; AgNOR proteins; desmoid tumours

\section{Introduction}

Desmoid-type fibromatoses are clonal fibroblastic proliferations that arise in the deep soft tissues and are characterized by infiltrative growth and a tendency toward local recurrence but by inability to metastasize [1]. Desmoids are composed of fibrocytes, fibroblasts and myofibroblasts surrounded and separated by abundant collagen or foci with mucoid stroma $[1,2]$. Desmoid

Correspondence: L. Stalińska, Dept. of Biology and Medical Genetics, Medical University, Pl. Hallera 1, 90-647 Łódź,

Poland; tel./fax.: (+4842) 6330594,

e-mail: liliana.stalinska@gmail.com tumours are characterized by the proliferation of reperative type myofibroblasts [3].

Tumour proliferation represents the convergence of many cellular factors, including cell cycle time, growth fraction, population doubling time, and cell loss. These factors depend upon the cell cycle phases [4-6]. The proliferative capacity of tumour cells is a fundamental feature of tumour growth [7]. Information about the cellular proliferation rate on paraffin sections of the same tissue can be obtained by immunohistochemical detection of the Ki-67 protein [5,7-9], minichromosome maintenence (MCM) proteins [1015], and the histochemical assessment of silver-stained AgNOR proteins $[16,17]$. 
Table 1. The examined group of desmoid tumour cases.

\begin{tabular}{|l|c|c|c|c|}
\hline \multicolumn{1}{|c|}{$\begin{array}{c}\text { Tumour } \\
\text { location }\end{array}$} & $N$ & $\begin{array}{c}\text { Female } \\
n\end{array}$ & $\begin{array}{c}\text { Male } \\
n\end{array}$ & $\begin{array}{c}\text { Mean age } \\
\text { (range) }\end{array}$ \\
\hline Abdominal & 18 & 18 & 0 & $\begin{array}{c}29.4 \\
(17-41)\end{array}$ \\
\hline Fxtra-abdominal & $10(12)^{* *}$ & $6(8)^{*}$ & 4 & $\begin{array}{c}35.8 \\
(15-68)\end{array}$ \\
\hline Intra-abdominal & 2 & 1 & 1 & $\begin{array}{c}33.0 \\
(30-36)\end{array}$ \\
\hline Total & $30(32)^{*}$ & $25(27)^{* *}$ & 5 & $\begin{array}{c}32.1 \\
(15-68)\end{array}$ \\
\hline
\end{tabular}

* two additional cases were included for the testing of MCM proteins expression

MCM proteins are essential for the initiation and progression of DNA replication in eukaryotes. Among them the best known are MCM2-7, a family of six highly conserved proteins which are key components of the prereplicative complex (pre-RC) that initiates DNA synthesis in all eucaryotes [18-20]. The minichromosome maintenace genes (MCM2-7) are transcribed at M/G1 phase boundary [21]. The nuclear localization of the MCM2-7 complex is regulated by the cyclin-dependent kinases (CDKs) [18,20-22]. MCM2-7 are imported into the nucleus when CDK activity is low in early G1 and exported from the nucleus during $\mathrm{S}$ phase when CDK activity is high [21]. In mammalian cells in G1 phase majority of MCM proteins are associated with chromatin. In $\mathrm{S}$ phase nearly the whole amount of MCM proteins dissociate from the chromatin and only small fraction of them remains bound to regions of unreplicated DNA $[18,21]$. During G2/M phase MCM proteins are absent on chromatin and are detectable predominantly in cytoplasm where they later undergo enzymatic degradation $[18,21]$. As cells exit mitosis these newly synthesized MCM proteins accumulate in the nucleus (early G1 phase) and assemble into pre-RC [21]. Human MCM2-MCM7 have recently been considered as new proliferating antigens $[10,13,14,23,24]$.

Nucleolar organizer regions (NORs) are ribosomal DNA (rDNA) sequences on the short arms of human acrocentric (D and $\mathrm{G}$ group) chromosomes, which encode ribosomal RNA (rRNA) [25]. In cycling cells, the rDNAs are expressed from telophase to the end of G2 phase [26]. The AgNORs were displayed by a silver staining technique that selectively stains some acid proteins (AgNOR proteins) associated with ribosomal genes [27,28]. Silver-stained NORs are defined as AgNORs and the argyrophilic NOR proteins as AgNOR proteins [17,29]. Biochemical investigations have revealed that two fundamental proteins, nucleolin and nucleophosmin, are the major AgNOR proteins $[26,29]$. Nucleolin is a phosphoprotein of $105 \mathrm{kDa}$ which plays an important role in the transcription of rRNA molecules, and nucleophosmin (or B23 protein) is a phosphoprotein of $38-39 \mathrm{kDa}$ which is engaged in the late steps of pre-ribosomal particle organization [29]. The quantity of nucleolins and nucleophosmins progressively increases from early G1 phase, reaches a maximum value at the end of S phase and remains constant up to the late $G 2$ phase $[26,29,30]$. It has been postulated that the quantity of AgNOR proteins as detected by the silver staining is directly correlated with transcriptional activity and proliferation rate of the cell $[17,29]$. AgNORs can be visualised in routine histological or cytological preparations as black or dark brown dots in the interphase nucleus [27]. Evaluation of the quantitative distribution of interphase AgNORs has been applied in tumour pathology both for diagnostic and prognostic purposes [17,29,31].

By using tissue microarray (TMA)-based immunohisochemistry, we aimed at analyzing the expression patterns of MCM2, MCM5 and MCM7 proteins, and by using histochemical method of AgNOR proteins in desmoid tumour cells. Additionally we examined immunohistochemically the expression of Ki-67, a conventional proliferating antigen.

\section{Material and methods}

Formalin-fixed, paraffin-embedded archival tissues of 32 sporadic aggressive fibromatosis (desmoid) were studied. Table 1 presents the characteristics of the studied group. The tissues examined in this study were collected from the same cases which were previously discussed by Stalinska et al. [32].

The analysed archival material was collected from the Polish Departments of Tumor Pathology*. All the sections were independently examined by two pathologists (AK, JS), using a conference microscope and they were histopathologically classified, as recommended by The World Health Organization Classification of Tumours (2002) [1] and Weiss, Goldblum [2]. The study was carried out with full approval of the Local Ethics Committee.

Tissue microarray (TMA). The paraffin-embedded tumour tissues were used for constructing TMA blocks and studied for MCM2, MCM5, MCM7 and Ki-67 expression by immunohistochemistry and argyrophilic nucleolar organiser proteins (AgNORs) by histochemical method. Haematoxylin and eosin (H\&E) stained sections were made from paraffin blocks in order to mark the representative tumour regions. The TMAs were constructed as previously described [3336]. From each specimen triplicate $2.0 \mathrm{~mm}$ tissue cores were punched and arrayed on a recipient paraffin block. Soft tissue tumours are relatively homogenous so the core samples should be representative of the entire lesion [37]. The $5 \mathrm{~m}$ thick sections of tissue array blocks were cut and placed on charged polylysine-coated slides (SuperFrost (RPlus, Menzel-Glaser, Brunschweig, Germany). The TMA composed of tonsil samples were used as positive control.

Immunohistochemical staining. The $5 \mu \mathrm{m}$ thick TMA sections were dried overnight at $60^{\circ} \mathrm{C}$, then deparaffinized and rehydrated. An antigen retrieval was performed by pretreatment in Target Retrieval Solution Citrate ( $\mathrm{pH}$ 6.0) (DAKO Cytomation, DK) in a waterbath $\left(95-99^{\circ} \mathrm{C}, 40 \mathrm{~min}\right.$.). The sections were subsequently rinsed with $3 \%$ hydrogen peroxide for $10 \mathrm{~min}$. at room temperature and then they were incubated with primary mouse monoclonal 

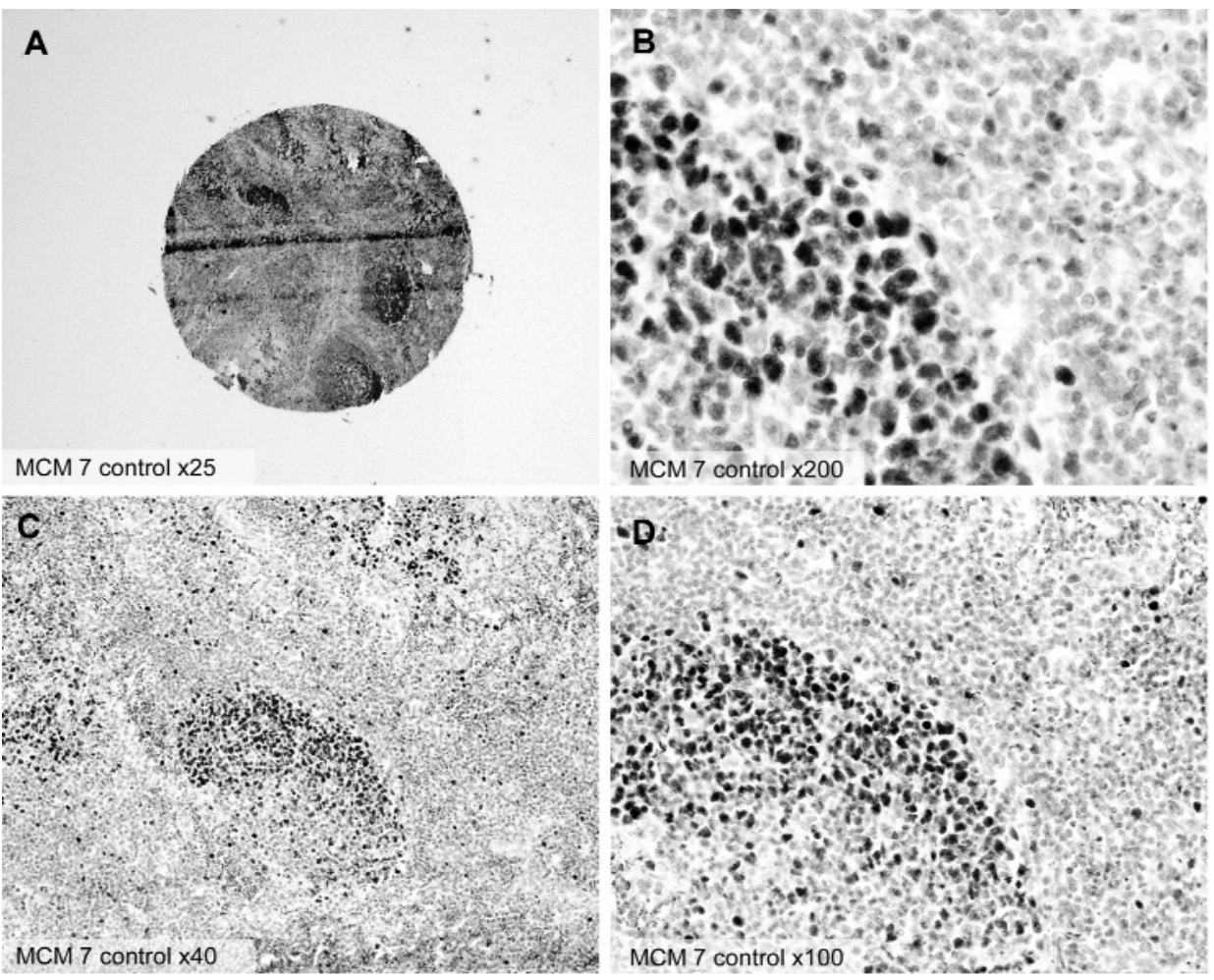

Fig. 1. Immunoreactivity of MCM7 in tonsil using tissue microarray. Representative images of positive expression are shown. Nuclei were counterstained with Mayers hematoxilin. (A) MCM7 control (original magnification $\times 25)$; (B) MCM7 control (original magnification $\times 40$ ); (C) MCM7 control (original magnification $\times 100)$; (D) MCM7 control (original magnification $\times 200)$.

antibodies for 1 hour at room temperature. The protein expression was detected using LSAB ${ }^{\circledR}+$ SYSTEM-HR reagent (DAKO, Cytomation, DK). 3,3'-diaminobenzidine (Liquid DAB + Chromogen) (DAKO, Cytomation, DK) was used as chromogen to yield brown reaction product. The sections were counterstained with Mayers hematoxylin (DAKO, Cytomation, DK), dehydrated and mounted. Negative controls were obtained by omission of the primary antibody with substitution by non-specific immunoglobulins. The mouse monoclonal antibodies were obtained in this study from the Novocastra (Newcastle upon Tyne, UK) and diluted for staining as follows: anti-MCM 2 (clone CRCT2.1), 1:50; antiMCM5 (clone CRCT5.1), 1:25; anti-MCM7 (clone DCS-141.1), 1:25, and Ki-67 (MIB-1) (DAKO, Cytometation, DK), 1: 50. The TMA embedded tonsil sections were used as positive control for MCM2, MCM5, and MCM7 (Fig. 1). The immunohistochemical reaction for CD34 (clone QBEnd/10), (Novocastra, Newcastle upon Tyne, UK), dilution 1:50, was performed for each case.

Immunohistochemical analysis. A semiquantitative approach was used for scoring the immunostaining [38]. The evaluation and scoring of immunostaining was independently undertaken by two pathologists (JS and JK); whenever necessary, a consensus was reached using a double-headed microscope. The immunostaining was also classified according to the location of the nucleus. The MCM2, MCM5, MCM7 and Ki-67 were defined as positive cases if $5 \%$ of all tumour cells stained positively [39]. The percentage of positive cells was counted in each examined case in 10 high-power fields (HPF) with $40 \times$ magnification of the objective lens. The labeling index (LI) for MCM2, MCM5, MCM7, and K-67 immunoreactivity was made by scoring positive nuclei as a percentage of the total number of the counted nuclei.

AgNORs staining. AgNORs staining was performed as reported by Ploton et al. [27]. TMA sections, $5 \mu \mathrm{m}$ thick, were oven dried overnight at $60^{\circ} \mathrm{C}$, then deparaffinized in xylene and following this, hydrated through 3 decreasing concentrations of ethanol to distilled water. The AgNOR staining solution was composed of one volume of $2 \%$ solution of gelatin (Sigma, USA) in 1\% aqueous formic acid (Sigma, USA) and two volumes of $50 \%$ silver nitrate (Sigma, USA). The staining reaction was performed for 16 minutes in a dark chamber at $37^{\circ} \mathrm{C}$. After washing, the sections were dehydrated through graded concentration of alcohol to xylene and mounted in a synthetic medium.

Morphometric analysis of AgNORs. Silver stained specimens were examined using BX-41 OLYMPUS microscope equipped with a PlanC $\times 100 / 1.25$ oil lens. The images were digitized and transferred directly into the computer with OLYMPUS C-5060 digital camera and QuickPHOTO PRO v.2.0 software with the resolution $2592 \times 1944$ pixels. Semiautomated image processing performed with Imagej v.1.34, included: conversion into 8 bit image, background, normalization, highpass filtration, segmentation, binary processing and final measurements. The number of the analysed nuclei from each patient was 180-215. The nuclei were chosen for the analysis systematically. The lymphocytes from maturation region of lymphatic nodules of palatine tonsil were the control group. The AgNOR analysis was in accordance with the recommendations of the 'Committee on AgNOR Quantification' within the European Society of Pathology [40]. The following morphometric parameters were assessed: number of cell nuclei, AgNOR dot number, and AgNOR area. The mean number AgNORs per nucleus $(N)$ and the mean AgNOR area per silver-stained NOR particle (dot) $(A)$ were calculated according to:

$$
N=\frac{\Sigma(\text { AgNORs })}{\text { No. of cells }}, \quad A=\frac{\Sigma(\text { Area of } A g N O R s)}{\text { No. of } A g N O R s} .
$$

The quotient of these parameters was regarded as an equivalent of the AgNOR content of a given cell or tumor $(\mathrm{C}=\mathrm{N} / \mathrm{A})$ [41]. 
Table 2. The tumour location of extra-abdominal aggressive fibromatosis cases.

\begin{tabular}{|l|c|}
\hline \multicolumn{1}{|c|}{ liumour location } & Number of cases \\
\hline Ihoracic wall & 5 \\
\hline Amm & 2 \\
\hline Poplitcal fossa & 1 \\
\hline Neck & 1 \\
\hline Coax & 1 \\
\hline Buttock & 1 \\
\hline Spinal region & 1 \\
\hline
\end{tabular}

Table 3. Immunohistochemical findings in the examined group of desmoid tumours.

\begin{tabular}{|c|c|c|c|c|}
\hline Protcins & $\mathrm{n}$ & $\mathrm{N}(\%)$ & $\begin{array}{c}\text { Mean of percentage of } \\
\text { cells staining positive, } \\
\geq 5 \%( \pm \mathrm{S} D)\end{array}$ & Range \\
\hline MCM2 & 32 & $\begin{array}{c}0 \\
(0)\end{array}$ & $0.0(0.0)$ & 0 \\
\hline MCM5 & 32 & $\begin{array}{c}0 \\
(0)\end{array}$ & $0.0(0.0)$ & 0 \\
\hline MCM7 & 20 & $\begin{array}{c}4 \\
(20.0)\end{array}$ & $0.87( \pm 1.64)$ & $0-5.0 \%$ \\
\hline Ki-67 & 21 & $\begin{array}{c}4 \\
(19.0)\end{array}$ & $0.81( \pm 1.65)$ & $0-5.0 \%$ \\
\hline
\end{tabular}

$\mathrm{n}$ - number of examined cases, $\mathrm{N}(\%)$ - percentage of positive cases

Statistical analysis. The basic statistical analysis (arithmetic mean, range, standard deviation) was performed. The comparisons between the groups and the analysis of the dependences were performed with chi ${ }^{2}$ test and Fisher's exact test. Pearson correlation coefficient was applied to compare the expression of MCM and $\mathrm{Ki}$ 67 proteins. The statistical analysis of the AgNOR parameters was performed using regression analysis ANOVA. The value of $p<0.05$ was regarded as statistically significant.

\section{Results}

The clinical data of the examined cases of desmoids of extra-abdominal location are given in Table 2 . Among tumours of abdominal location 11 cases occurred in abdominal wall and 7 in musculus rectus. One of the tumours located intra-abdominally was found in pelvis minor, the other in retroperitoneal space.

\section{MCM2, MCM5, MCM7 and Ki-67 proteins analysis}

Mean values of the percentage of MCM2, MCM5, MCM7 and Ki-67-positive cells are presented in Table 3. MCM7 nuclear expression was found in $20 \%$ (4/20) of desmoid cases ( $\geq 5 \%$ of tumour nuclear staining), where mean percentage of positive
Table 4. Standardized AgNOR parameters score in the examined desmoid tumours.

\begin{tabular}{|c|c|c|c|c|}
\hline \multirow{2}{*}{} & \multicolumn{4}{|c|}{ AgNOR paramelers (mean, $\pm \mathrm{SD})$} \\
\cline { 2 - 5 } & $\begin{array}{c}\Lambda \mathrm{gNOR} \\
\text { number } \\
\text { per } \\
\text { nucleus }\end{array}$ & $\begin{array}{c}\Lambda \mathrm{gNOR} \\
\text { area } \\
\text { per } \\
\text { nucleus } \\
\left(\mu \mathrm{m}^{2}\right)\end{array}$ & $\begin{array}{c}\Lambda \mathrm{gNOR} \\
\text { dot area } \\
\text { per } \\
\text { nucleus } \\
\left(\mu \mathrm{m}^{2}\right)\end{array}$ & $\begin{array}{c}\text { AgNOR } \\
\text { content }\end{array}$ \\
\hline $\begin{array}{c}\text { Tumour } \\
\text { tissue } \\
(n=30)\end{array}$ & $\begin{array}{c}4.34 \\
( \pm 0.11) *\end{array}$ & $\begin{array}{c}0.74 \\
( \pm 0.03)\end{array}$ & $\begin{array}{c}0.18 \\
( \pm 0.01)\end{array}$ & $\begin{array}{c}2.3 .73 \\
( \pm 1.85)^{* *}\end{array}$ \\
\hline $\begin{array}{c}\text { Tonsil } \\
\text { tissue } \\
\text { (control) }\end{array}$ & $\begin{array}{c}1.75 \\
( \pm 0.73)\end{array}$ & $\begin{array}{c}0.56 \\
( \pm 0.06)\end{array}$ & $\begin{array}{c}0.32 \\
( \pm 0.10)\end{array}$ & $\begin{array}{c}5.47 \\
( \pm 0.87)\end{array}$ \\
\hline
\end{tabular}

* $\mathrm{p}<0.001$ compared to the control

cells was $0.87(\mathrm{SD} \pm 1.64)$ (range $0-5 \%)$ (Fig. 2). In the remaining cases there was lack of MCM7 protein expression or only single cells were noted with nuclear staining for this protein. In $100 \%$ (32/32) of the examined cases with desmoid tumour no nuclear staining was detected for MCM2 and MCM5 proteins. Ki-67 nuclear expression was observed in $19.0 \%(4 / 21)$ of the desmoid cases $(\geq 5 \%$ of tumour nuclear staining), where the mean percentage of positive cells was $0.81 \%(\mathrm{SD} \pm 1.65)$ (range $0-5 \%)$. In the remaining cases no nuclear expression was detected for this protein neither the presence of single Ki-67-positive cells was noted.

CD34 antigen is commonly used to distinguish aggressive fibromatosis from other mesenchymal tumours, including GISTs (Gastrointestinal Stromal Tumours). Desmoid cells do not show the expression of this antigen. In the present study all 32 examined cases were CD34-negative.

\section{AgNORs analysis}

The distribution of standardised AgNOR parameters is summarized in Table 4 . The mean values of AgNOR parameters for the examined group $(n=30)$ were the following: number: $4.34( \pm 0.11)$, area: 0.74 $\mu \mathrm{m}^{2}( \pm 0.03)$, dot area: $0.18 \mu \mathrm{m}^{2}( \pm 0.01)$, and $A g N O R$ content: 23.73 ( \pm 1.85$)$ (Fig. 3). No statistically significant differences were found between the abdominal $(n=18)$ and extra-abdominal location $(n=10)$ for the examined AgNOR parameters $(p>0.1)$. In the control tissue (tonsil) the mean values of AgNOR parameters were as follows: number: $1.75( \pm 0.73)$, area: $0.56 \mu \mathrm{m}^{2}( \pm 0.06)$, dot area: $0.32 \mu \mathrm{m}^{2}( \pm 0.10)$, and AgNOR content: 5.47 ( 0.87). The mean AgNOR number per nucleus and mean $A g N O R$ content in desmoid tumours was statistically significantly higher as compared to the control $(\mathrm{p}<0.001)$. 

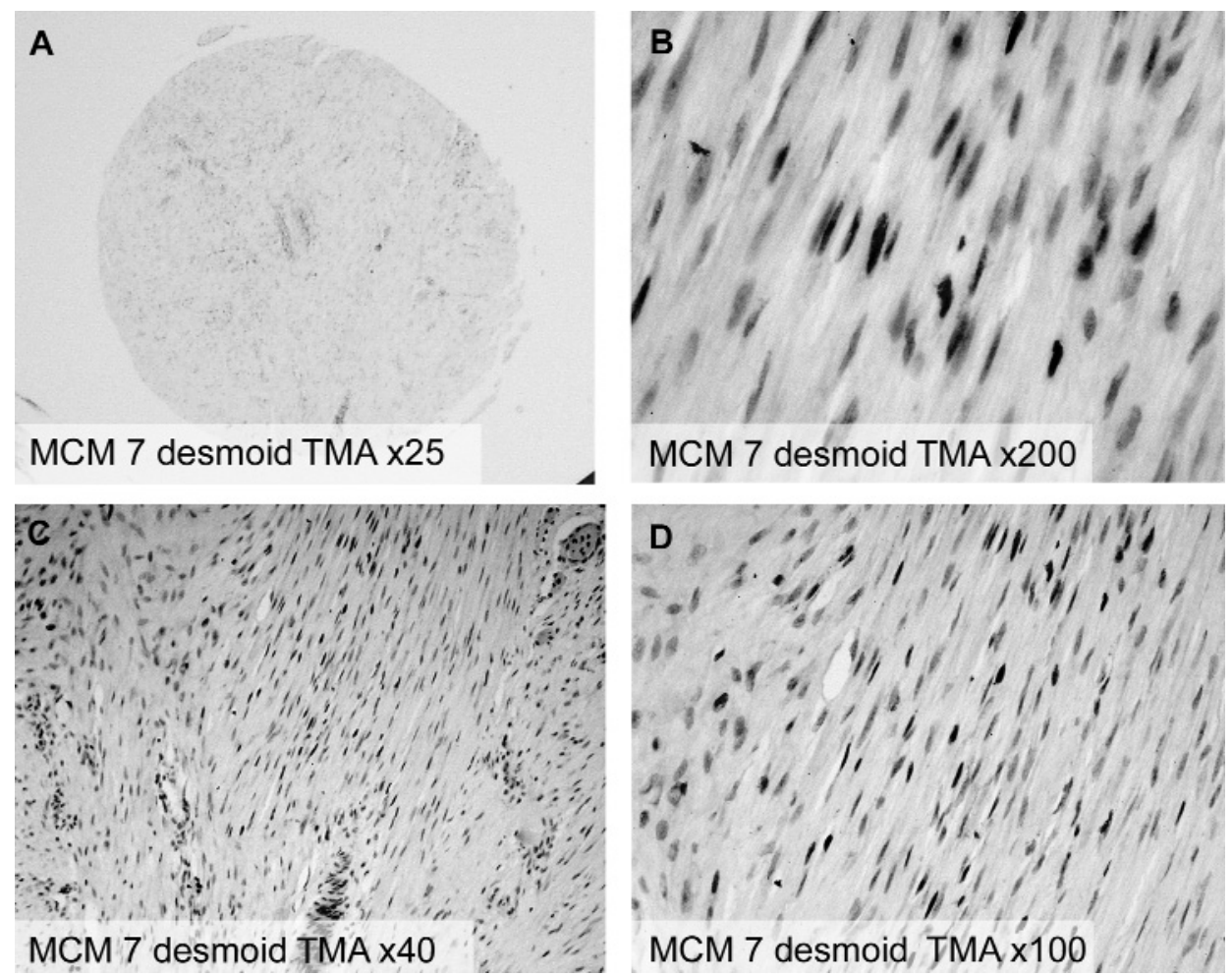

Fig. 2. Immunoreactivity of MCM7 in desmoid tumour using tissue microarray. Representative images of positive expression are shown. Nuclei were counterstained with Mayers hematoxilin. (A) MCM7 desmoid (original magnification $\times 25$ ); (B) MCM7 desmoid (original magnification $\times 40$ ); (C) MCM7 desmoid (original magnification $\times 100$ ); MCM7 desmoid (original magnification $\times 200$ ).
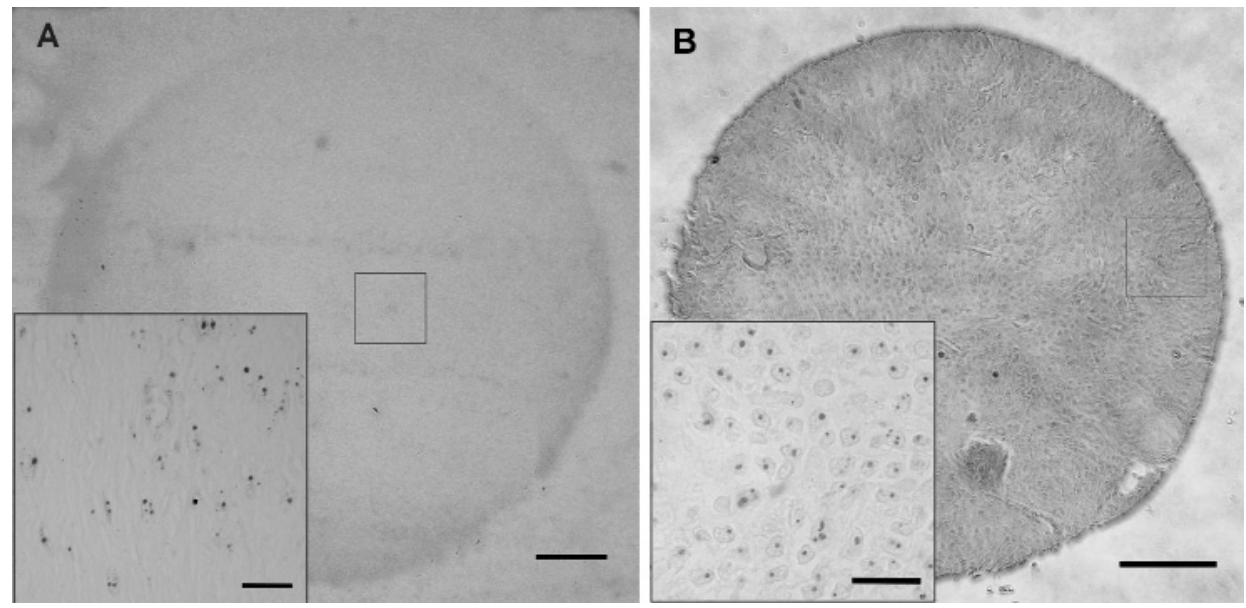

Fig. 3. Representative images of a tissue microarray for AgNOR staining in desmoid tumour (A) and tonsil (B; control) (the line on a large image corresponds to $250 \mu \mathrm{m}$, the line on a small image corresponds to $25 \mu \mathrm{m})$.

\section{Discussion}

In the available literature there is only one report related to the studies on the expression of MCM5 protein in desmoid tumour cells with the use of immunohistochemistry [32]. However, MCM2 - MCM7 proteins have been investigated with this method as proliferation markers in different types of neoplasms, including: oesophageal cancer [11,13], myxofibrosarcoma [23], breast cancer [14], gastrointestinal stromal tumours (GISTs) [15]. Freeman et al. [10] examined the expression of MCM2, MCM5 and MCM7 proteins in tissue from various malignancies. As far as GISTs are concerned, Huang et al. [15] qualified the values of
LI $>10 \%$ of tumor nuclear staining as cases MCM2positive. In our study no positive cases were found for MCM2 and MCM5 proteins. However, the expression of MCM7 protein was observed in $4(20 \%)(\geq 5 \%$ of tumour nuclear staining) of the 20 examined desmoid cases. Taking into account other neoplasms in respect of MCM7, Ren et al. [24] analysed MCM7 expression with immunohistochemical method in prostatic tissues from both benign and aggressive lesions. In $61.4 \%$ $(62 / 101)$ of aggressive cases of prostate cancer the level of MCM7 protein expression was $\geq 20 \%$ of positive cells. In the cases of benign lesions the percentage of positive cells did not reach the value of $20 \%$ in any of the analysed cases [24]. In the same study the 
authors investigated the number of copies of $M C M 7$ gene in benign lesions and aggressive prostate cancers. The amplification of MCM7 gene was not detected in any of the examined benign lesions, however it was observed in $45 \%(26 / 58)$ of aggressive prostatic cancers [24]. In the studies on endometrial carcinoma $\mathrm{Li}$ et al. [7] noted the correlation between the level of MCM7 protein expression and the grade of histological malignancy of this carcinoma and the patients' age at the time of the diagnosis. In patients younger than 45 years of age and in the cases of well-differentiated endometrial carcinoma the level of MCM7 expression was statistically significantly lower than in patients in whom the carcinoma was poorly differentiated. Furthermore, the level of MCM7 expression appeared to be an independent prognostic factor of survival in patients with endometrial carcinoma [7]. Xue et al. [12] analysed the expression of MCM7 protein in various forms of gestational trophoblastic diseases (GTD). In the cases of malignant choriocarcinoma the level of MCM7 protein expression was statistically significantly higher than in the cases of partial or complete hydatidiform mole. On the other hand, in complete hydatidiform mole MCM7 expression was statistically significantly higher than in the tissue of normal 3-month placenta from spontaneous abortion [12]. MCM7 labeling index (LI) can also be used as a marker of glioma grade since it appeared to be useful in the discrimination between the samples with prevalent oligodendroglial component and samples with a smallcell component [42].

In this study we also examined the expression of conventional proliferating antigen, Ki-67, which was subjected to immunohistochemical analysis by other researchers in desmoid tumour. Saito et al. [43] examined $\mathrm{Ki}-67$ expression in 38 cases of aggressive fibromatosis without familial adenomatous polyposis (FAP). In majority of cases the authors found no positive reaction to this antigen or they observed single cells with nuclear staining for Ki-67. In this study, the mean value of the labeling index (LI) calculated for Ki-67 was 3.0 (0-28.0) [43]. Hoos et al. [44] did not find nuclear staining for $\mathrm{Ki}-67$ in 24 of the examined cases of aggressive fibromatosis. Neither Kouho et al. [45] detected any cells (or were few) with nuclear staining of $\mathrm{Ki}-67$ in 24 desmoid cases.

Leithner et al. [39] examined 80 cases of desmoid tumour. They classified the cases as positive at the value of $\geq 5 \%$ of cells with clear nuclear staining for $\mathrm{Ki}-67$. Basing on this criterion 20 out of $80(25 \%)$ of the examined desmoid cases were positive for Ki-67. Among these 20 positive cases, in 18 the expression of $\mathrm{Ki}-67$ was detected in $5-10 \%$ of cells and only in 2 cases it was $>10 \%$ of cells with nuclear staining [39]. In the study of Gebert et al. [46] thirty six of 37 cases showed MIB1 expression in $\leq 2 \%$ of the tumour cells.
In one case MIB1 expression was apparent in $5 \%$ of the tumour cells. In our study in 4 of $21(19 \%)$ cases the expression of $\mathrm{Ki}-67$ proteins was $5 \%$.

A lot of studies have been already presented on AgNORs in human neoplasms derived from various tissues e.g. [16,28,31]. Khan et al. [47] examined 74 benign and 36 malignant soft tissue tumours. The mean AgNOR count in malignant tissue was $4.96( \pm 1.33)$, which was found to be higher as compared to both normal appearing soft tissues and benign soft tissues tumours. The results were found to be statistically significant [47]. So far, only few works have been available concerning the analysis of AgNORs in aggressive fibromatosis tumours [48-49]. Egan et al. [48] examined 16 cases of fibrous proliferations of childhood. The fibrous proliferations composed five cases of infantile digital fibromatosis, seven infantile desmoids type fibromatosis and four of infantile myofibromatosis. These authors demonstrated that the mean number of AgNORs in fibromatoses is 3.7 (range 2.7-5.9) [48]. Schmidt et al. [49] investigated AgNORs in 27 cases of infantile desmoid-type fibromatosis. The AgNOR number per cell varied considerably from case to case, with a median number of 4 (range 1.6-7.5). The authors noted marked differences in AgNOR size - the size varied between 0.14 and $0.45 \mu \mathrm{m}^{2}$ (median $0.25 \mu^{2}$ ) [49]. They found no correlation between AgNOR features and the clinical course in 11 cases in which these studies were performed simultaneously [49].

In our study, in 30 examined desmoid cases, the mean AgNOR number per nucleus was $4.34( \pm 0.11)$, the mean AgNOR area per nucleus was $0.74( \pm 0.03)$, and the mean value of AgNOR dot area was: $0.18( \pm 0.01)$. The high value of AgNOR content in the examined group of desmoids caught the attention. Its mean value was here $23.73( \pm 1.85)$ and it was statistically significantly higher as compared to the control group where it was $5.47( \pm 0.87)(p<0.001)$. The number of interphase AgNORs is strictly related to rRNA transcriptional activity [17,29]. Taking this into consideration, the results obtained in the present study concerning the number of AgNORs might be associated with the elevated synthesis of collagen in desmoid cells.

In this study, we have concluded that the low level of MCM7, Ki-67 and lack of MCM2, MCM5 proteins expression may explain commonly known low mitotic activity of desmoid tumour cells. Morphology of AgNOR dots (number, area) and their morphometric parameters point to the elevated transcriptional activity of desmoid cells.

Acknowledgements: This work was supported by the grant No. 3P05A 03324 from the National Committee for Scientific Research, Poland. *The authors of this research are grateful to the below mentioned Heads of Chairs and Departments for providing paraffin blocks and available data for the realisation of this studies: The Chair of Pathomorphology, Collegium Medicum of Jagiellon- 
ian University in Kraków; The Department of Neoplasms Pathology, Center of Oncology, M. Skłodowska-Curie Institute, Kraków; The Department of Neoplasms Pathology, Center of Oncology, M. Skłodowska-Curie Institute, Gliwice; The Chair and Department of Pathological Anatomy, Medical University in Białystok; The Chair and Department of Clinical Pathomorphology, K. Marcinkowski Medical University in Poznań; The Chair and Department of Pathological Anatomy, Medical University in Gdańsk; The Chair and Department of Pathological Anatomy, Silesian Medical University in Katowice; Department of Pathomorphology, Provincial Hospital in Rzeszów.

\section{References}

[1] Goldblum JR, Fletcher JA. Desmoid-type fibromatosis. In Fletcher CDM, Unni KK, Mertens F eds. Pathology an Genetics of Tumours of Soft Tissue and Bone. World Health Organization Classification of Tumours. IARC Press: Lyon' 2002:83-84.

[2] Weiss SH, Goldblum JR. Enzinger and Weiss's soft tissue tumors (fourth edition). St. Luis: Mosby. 2001;309-346.

[3] Dominguez-Malagon H. Intracellular collagen and fibronexus in fibromatosis and other fibroblastic tumors. Ultrastruct Pathol. 2004;28:67-73.

[4] Hirama T, Koeffler HP. Role of the cyclin - dependent kinase inhibitors in the development of cancer. Blood. 1995;86:841-854.

[ 5] Quinones-Hinojosa A, Sanai N, Smith JS, McDermott MW. Techniques to assess the proliferative potential of brain tumors. J Neuro-Oncol. 2005;74:19-30.

[6] Tachibana KK, Gonzalez MA, Coleman N. Cell-cycle-dependant regulation of DNA replication and its relevance to cancer pathology. J Pathol. 2005;205:123-129.

[7] Li SS, Xue WC, Khoo US, et al. Replicative MCM7 protein as a proliferation marker in endometrial carcinoma: a tissue microarray and clinicopathological analysis. Histopathology. 2005;46:307-313.

[ 8] Linden MD, Torres FX, Kubus J, Zarbo RJ. Clinical application of morphologic and immunocytochemical assessment of cell proliferation. Am J Clin Pathol. 1992;97:Suppl 1, S4-13.

[9] Scholzen T, Gerdes J. The Ki-67 protein: from the known and the unknown. J Cell Physiol. 2000;182:311-322.

[10] Freeman A, Morris LS, Mills AD, et al. Minichromosome maintenance proteins as biological markers of dysplasia and malignancy. Clin Cancer Res. 1999;5:2121-2132.

[11] Going JJ, Keith WN, Neilson L, et al. Aberrant expression of minichromosome maintenance proteins 2 and 5, and $\mathrm{Ki}-67$ in dysplastic squamous oesophageal epithelium and Barrett's mucosa. Gut 2002;50:373-377.

[12] Xue WC, Khoo US, Ngan HY, et al. Minichromosome maintenance protein 7 expression in gestational trophoblastic disease: correlation with Ki-67, PCNA and clinicopathological parameters. Histopathology. 2003;43:485-490.

[13] Williams GH, Swinn R, Prevost AT, et al. Diagnosis of oesophageal cancer by detection of minichromosome maintenance 5 protein in gastric aspirates. $\mathrm{Br} J$ Cancer. 2004;91:714 -719.

[14] Shetty A, Loddo M, Fanshawe T, et al. DNA replication licensing and cell cycle kinetics of normal and neoplastic breast. Br J Cancer. 2005;93:1295-1300.

[15] Huang HY, Huang WW, Lin CN, et al. Immunohistochemical expression of p16INK4A, Ki-67, and Mcm2 proteins in gastrointestinal stromal tumors: prognostic implications and correlations with risk stratification of NIH consensus criteria. Ann Surg Oncol. 2006;13:1633-1644.

[16] Piffko J, Bankfalvi A, Öfner D, et al. Prognostic value of histobiological factors (malignancy grading and AgNOR con- tent) assessed at the invasive tumour front of oral squmous cell carcinomas. Br J Cancer. 1997;75:1543-1546.

[17] Derenzini M, Trere D, Pession A, Montanaro L, Sirri V, Ochs RL. Nucleolar function and size in cancer cells. Am J Pathol. 1998;152:1291-1297.

[18] Kearsey SE, Labib K. MCM proteins: evolution, properties, and role in DNA replication. Biochim Biophys Acta. 1998;1398:113-136.

[19] Tye BK. MCM proteins in DNA replication. Annu Rev Biochem. 1999;68:649-686.

[20] Sclafani RA, Holzen TM. Cell cycle regulation of DNA replication. Annu Rev Genet. 2007;41:237-280.

[21] Labib K, Kearsey SE, Diffley JFX. MCM2-7 proteins are essential components of prereplicative complexes that accumulate cooperatively in the nucleus during G1-phase and are required to establish, but not maintain, the S-phase checkpoint. Mol Biol Cell. 2001;12:3658-3667.

[22] Braun KA, Breeden LL. Nascent transcription of MCM2-7 is important for nuclear localization of the minichromosome maintenance complex in G1. Mol Biol Cell. 2007;18:14471456.

[23] Sington JD, Freeman A, Morris LS, et al. Minichromosome maintenance protein in myxofibrosarcoma. Mod Pathol. 2004; 17:235-240

[24] Ren B, Yu G, Tseng GC, et al. MCM7 amplification and overexpression are assiciated with prostate cancer progression. Oncogene. 2006;25:1090-1098.

[25] Trent JM, Carlin DA, Davis JR. Expression of silver-stained nucleolar organizing regions (Ag-NORs) in human cancer. Cytogenet Cell Genet. 1981;30:31-38.

[26] Sirri V, Roussel P, Gendron M-C, Hernandez-Verdun D. Amount of the two major Ag-NOR proteins, nucleolin, and protein B23 is cell cycle dependent. Cytometry. 1997;28:147-156.

[27] Ploton D, Menager M, Jeannesson P, Himber G, Pigeon F, Adnett JJ. Improvement in the staining and in the visualization of the argyrophilic proteins of the nucleolar organizer regions at the optical level. Histochem J. 1986;18:5-14.

[28] Matheus RS, Bernardi Fdel C, Gallo CP, et al. Nuclear markers (star volume, mitotic index, AgNOR and Ki-67) of the primary tumor and its metastasis in non-small lung carcinomas. Pathol Res Pract. 2004;200:13-23.

[29] Derenzini M. The AgNORs. Micron. 2000;31:117-120.

[30] Sirri V, Roussel P, Hernandez-Verdun D. The AgNOR proteins: qualitative and quantitative changes during the cell cycle. Micron. 2000;31:121-126.

[31] Pich A, Chiusa L, Margaria E. Prognostic relevance of AgNORs in tumor pathology. Micron. 2000;31:133-141.

[32] Stalinska L, Turant M, Tosik D, et al. Analysis of pRb, P16INK4A protein and proliferating antigens: PCNA, Ki-67 and MCM5 expression in aggressive fibromatosis (desmoid tumor). Histol Histopathol. 2009;24:299-308.

[33] Kononen J, Bubendorf L, Kallioniemi A, et al. Tissue microarrays for high-throughput molecular profiling of tumor specimens. Nat Med. 1998;4:844-847.

[34] Hoos A, Urist MJ, Stojadinovic A, et al. Validation of tissue microarrays for immunohistochemical profiling of cancer specimens using the example of human fibroblastic tumors. Am J Pathol. 2001;158:1245-1251.

[35] Han S, Park K, Bae BN, et al. Prognostic implication of cyclin E expression and its relationship with cyclin D1 and p27Kip 1 expression on tissue microarrays of node negative breast cancer. J Surg Oncol. 2003;83:241-247.

[36] Packeisen J, Korsching E, Herbst H, Boecker W, Buerger H. Tissue microarray technology. J Clin Pathol: Mol Pathol. 2003;56:198-204.

[37] West RB, van de Rijn M. The role of microarray technologies in the study of soft tissue tumours. Histopathology. 2006;48:22-31. 
[38] Walker RA. Quantification on immunohistochemistry -issues concerning methods, utility and semiquantitative assessment I. Histopathology. 2006;49:406-410.

[39] Leithner A, Gapp M, Radl R, et al. Immunohistochemical analysis of desmoid tumours. J Clin Pathol. 2005;58:11521156.

[40] Aubele M, Biesterfeld S, Derenzini M, et al. Guidelines of AgNOR quantitation. Committee on AgNOR Quantitation within the European Society of Pathology. Zentralbl Pathol. 1994;140:107-108.

[41] Rüschof J, Plate KH, Contractor H, Kern S, Zimmermann R, Thomas C. Evaluation of nucleolus organizer regions (NORs) by automatic image analysis: a contribution to standardization. J Pathol. 1990;161:113-118.

[42] Facoetti A, Ranza E, Benericetti E, Ceroni M, Tedeschi F, Nano R. Minichromosome maintenance protein 7: a reliable tool for glioblastoma proliferation index. Anticancer Res. 2006;26:3513-3516.

[43] Saito T, Oda Y, Tanaka K, et al. $\beta$-catenin nuclear expression correlates with cyclin D1 overexpression in sporadic desmoid tumours. J Pathol. 2001;195:222-228.
[44] Hoos A, Lewis JJ, Antonescu CR, et al. Characterization of molecular abnormalities in human fibroblastic neoplasms: a model for genotype-phenotype association in soft tissue tumors. Cancer Res. 2001;61:3171-3175.

[45] Kouho H, Aoki T, Hisaoka M, Hashimoto H. Clinicopathological and interphase cytogenetic analysis of desmoid tumours. Histopathology. 1997;31:336-341.

[46] Gebert C, Hardes J, Kersting C, et al. Expression of $\beta$-catenin and p53 are prognostic factors in deep aggressive fibromatosis. Histopathology. 2007;50:491-497.

[47] Khan N, Sood P, Vasenwala SM, Afroz N, Verma AK. Significance of AgNOR score in benign and malignant soft tissue tumours. Indian J Pathol Microbiol. 2006;49:17-20.

[48] Egan MJ, Raafat F, Crocker J, Smith K. Nucleolar organiser regions in fibrous proliferations of childhood and infantile fibrosarcoma. J Clin Pathol. 1988;41:31-33.

[49] Schmidt D, Klinge P, Leuschner I, Harms D. Infantile desmoid-type fibromatosis. Morphological features correlate with biological behaviour. J Pathol. 1991;164:315-319.

Submitted: 3 December, 2009 Accepted after reviews: 7 July, 2010 